\title{
Principal component analysis for heavy metals in hydrographic sub- basins of the rivers Capivari and Mortes/MG
}

Population growth and industrialization are correlated with the contamination of water resources by the release of untreated effluents into water sources. The objective of this work was to characterize heavy metals in sub-basins of the rivers Capivari and Mortes and the variability using principal component analysis (PCA). Three points were sampled at GD1 (P - I at Ingai - Minduri River, P - II at Capivari River and P - III at Ingai - Luminarias River) and three points at GD2 (P - IV at Mortes River, P - V at Peixe River and P - VI at Ribeirao dos Tabuoes). The monitoring period was from April 2015 to February 2016. Analysis of Aluminum, Bromine, Copper, Hexavalent Chromium, Iron, Manganese, Nickel and Zinc were evaluated. We compared the results with the Maximum Allowed Value in agreement with class 2, according to DN COPAM CERH 01/08. We also observed variables above the allowed value due to the discharge of domestic and industrial effluents, interference from precipitation and the contact between livestock and water sources. The principal components analysis (PCA) revealed that on average, the principal component 1 corresponds to $62.2 \%$ of the total variability of the data considering GD 1 , and, in GD 2, PC 1 is responsible for a higher average percentage of the total variability of the data, corresponding to $73.4 \%$, hence being more representative.

\section{Análise de componentes principais para metais pesados em sub- bacias hidrográficas dos rios Capivari e Mortes/MG}

\begin{abstract}
O crescimento populacional e a industrialização estão correlacionados à contaminação dos recursos hídricos pelo lançamento de efluentes não tratados em mananciais. O objetivo deste trabalho foi caracterizar metais pesados em sub-bacias dos rios Capivari e Mortes e a variabilidade por meio de análise de componentes principais (PCA). Três pontos foram amostrados no GD1 (P - I no Rio Ingai - Minduri, P - II no Rio Capivari e P - III no Ingai - Rio Luminarias) e três pontos no GD2 (P - IV no Rio Mortes, P - V no Peixe Rio e P - VI em Ribeirão dos Tabuões). O período de monitoramento foi de abril de 2015 a fevereiro de 2016. Foram avaliadas as análises de Alumínio, Bromo, Cobre, Cromo Hexavalente, Ferro, Manganês, Níquel e Zinco. Comparamos os resultados com o Valor Máximo Permitido de acordo com a classe 2, conforme DN COPAM CERH 01/08. Observamos também variáveis acima do valor permitido devido ao lançamento de efluentes domésticos e industriais, interferência da precipitação e do contato da pecuária com os mananciais. A análise de componentes principais (PCA) revelou que, em média, o componente principal 1 corresponde a $62,2 \%$ da variabilidade total dos dados considerando o GD 1, e, no GD 2, o PC 1 é responsável por um maior percentual médio da variabilidade total dos dados, correspondendo a 73,4\%, sendo, portanto, mais representativos.
\end{abstract}

Palavras-chave: Interferência antropogênica; Carga de poluição; Metais pesados.

Topic: Engenharia Agrícola

Reviewed anonymously in the process of blind peer.
Received: 02/04/2021

Approved: 27/04/2021
Diego Vipa Amâncio (iD)

Universidade Federal de Lavras, Brasil http://lattes.cnpq.br/2910168467280471 http://orcid.org/0000-0003-4047-7332 diegovipa@gmail.com

Gilberto Coelho (iD

Universidade Federal de Lavras, Brasil http://lattes.cnpq.br/9055295814917047

http://orcid.org/0000-0002-0654-2754

eng.gilbertocoelho@gmail.com

Rosângela Francisca de Paula Vitor Marques (iD

Universidade Federal de Lavras, Brasil

http://lattes.cnpq.br/6991929220004023

http://orcid.org/0000-0001-6646-0809

roeflorestal@hotmail.com

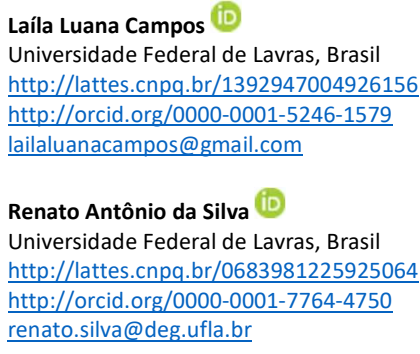

Universidade Federal de Lavras, Brasi http://lattes.cnpq.br/1392947004926156 http://orcid.org/0000-0001-5246-1579 lailaluanacampos@gmail.com

Renato Antônio da Silva

Universidade Federal de Lavras, Brasil http://lattes.cnpq.br/0683981225925064 http://orcid.org/0000-0001-7764-4750 renato.silva@deg.ufla.br

Referencing this:

AMÂNCIO, D. V.; COELHO, G.; MARQUES, R. F. P. V.; CAMPOS, L. L.; SILVA, R. A.. Principal component analysis for heavy metals in hydrographic sub-basins of the rivers Capivari and Mortes/MG. Revista Ibero Americana de Ciências Ambientais, v.12, n.4, p.93-104, 2021. DOI: http://doi.org/10.6008/CBPC2179-6858.2021.004.0010 


\section{INTRODUCTION}

The use and occupation of land in rural and urban water basins along with natural processes, such as precipitation, erosion and the weathering of rocks, drastically affects water quality, making it unsuitable for more demanding uses.

In recent decades, anthropogenic actions, both in urban and rural areas, have been responsible for the degradation of water resources. Thus, one of the factors that contributes the most to such degradation is the environmentally inappropriate discharge of effluents, hence causing several interferences in the environment and its organisms. Currently, detailed studies regarding the treatment and monitoring of water quality are extremely important, as it aims to provide with increasing information that intends to contribute to the environment conservation and results in future benefits. Water is an abundant resource in Brazil; however, it has an uneven distribution, being a limiting factor in some regions. In addition to the scarcity, the lack of adequate treatment and the release of solid and liquid waste into the bodies of water harm society.

Generally, the government aims, through legal mechanisms, to ensure as much as possible the maintenance of water quality, not disregarding its multiple uses (energy, transportation, recreation, supply, food production, industrial uses and sanitation, among others) and the development of a specific river basin. Among studies, the most solid criterion in relation to water resources gained strength and clarity only with the resolutions of the National Environment Council (CONAMA - Conselho Nacional do Meio Ambiente) and the Normative Deliberation of the Environmental Policy State Council (COPAM - Conselho Estadual de Política Ambiental), which aims to detail the predetermined physical, chemical and biological parameters in the watercourses. These parameters show what can compromise the use of water resources and harm humans and the environment, as a result of anthropogenic activities.

Heavy metals are stable and persistent environmental pollutants, since they cannot degrade and, depending on the physical and chemical characteristics of the aquatic environment, they react, disperse or are mobilized and deposited in sediments, representing a potential hazard due to the bioavailability characteristics they can acquire. In this context, the objective of this work was to characterize the values found for heavy metals along with DN COPAM 01/08 and, for a better interpretation, the use of Principal Component Analysis along the regions of Alto Rio Grande (GD1) and Vertentes of Rio Grande (GD2).

\section{METHODOLY}

The Capivari Basin is characterized by smaller towns, and its use and land occupation are predominantly agricultural. It presents a strong, wavy topography at the headwater, with the presence of Cambisols and a smooth wavy topography in the low regions of the UPGRH, where there is a predominance of Oxisols and Argisols, with altitudes ranging from 802 to 2,631 m. For the basin in this study, 3 sampling points in 3 sub-basins were selected, named P - I, P - II and P - III, respectively (Figure 1).

The Mortes Basin, on the other hand, is marked by larger towns and has characteristics of agricultural prevalence. The primary soils of the basin are oxisols. According to Vargas (2007), as the river mouth goes 
towards Mortes River, dystrophic red-yellow latosols, cambisols and litolic neossols appear more frequently. The use and occupation of land are the result of pasture and agriculture, urbanization, mining and fragments of native forest (IPT, 2008). We named the three sampling points for the monitoring in the sub-basin P - IV, $\mathrm{P}-\mathrm{V}$ and $\mathrm{P}-\mathrm{VI}$, respectively (Figure 1).

The two sub-basins present a climate characterized as humid (B3 and B4) according to the Thornthwaite classification, and might show precipitations above $1,600 \mathrm{~mm}$ and temperatures below $18^{\circ} \mathrm{C}$. The climate of the region is considered to have high humidity and low temperatures (MINAS GERAIS, 2008; OLIVEIRA, 2013).

Table 1 shows the six sampling points, with the geographic coordinates (latitude and longitude) and the altitude points, which were measured using an Adventure Garmin Map 64 Portable GPS.

We performed the flow measurement directly and indirectly, based on speed and level measurements. The devices used in the monitoring were the micro flow meter and the Qliner2. For the indirect measurement, the micro flow meter is more common. They are small propellers that rotate according to the water speed, and we used them in watercourses with depths under $30 \mathrm{~cm}$. For direct measurement, we used the Qliner 2. It is an electronic meter based on acoustic doppler and we used it in watercourses with depths over $30 \mathrm{~cm}$.

Table 1: Sampling points and their respective coordinates.

\begin{tabular}{lllll}
\hline Points & Coordinates & Altitude $(\mathrm{m})$ & Watercourses & UPGRH \\
\cline { 2 - 4 } & Latitude & Longitude & & Ingaí - Minduri \\
$\mathrm{P}-\mathrm{I}$ & $21^{\circ} 30^{\prime} 22.55^{\prime \prime S}$ & $44^{\circ} 54^{\prime} 56.84^{\prime \prime} \mathrm{O}$ & 995 & Capivari \\
$\mathrm{P}-\mathrm{II}$ & $21^{\circ} 28^{\prime} 40.69^{\prime \prime} \mathrm{S}$ & $44^{\circ} 45^{\prime} 57.26^{\prime \prime} \mathrm{O}$ & 863 & GD1 \\
$\mathrm{P}-\mathrm{III}$ & $21^{\circ} 30^{\prime} 22.76^{\prime \prime} \mathrm{S}$ & $44^{\circ} 54^{\prime} 56.59^{\prime \prime} \mathrm{O}$ & 898 & GD1 \\
$\mathrm{P}-\mathrm{IV}$ & $21^{\circ} 3^{\prime} 44.31^{\prime \prime S}$ & $44^{\circ} 18^{\prime} 41.93^{\prime \prime O}$ & 868 & GD1 \\
$\mathrm{P}-\mathrm{V}$ & $21^{\circ} 03^{\prime} 38.86^{\prime \prime} \mathrm{S}$ & $44^{\circ} 29^{\prime} 57.38^{\prime \prime} \mathrm{O}$ & 878 & Mortes \\
$\mathrm{P}-\mathrm{VI}$ & $21^{\circ} 4^{\prime} 49.61^{\prime \prime S}$ & $44^{\circ} 42^{\prime} 8.63^{\prime \prime} \mathrm{O}$ & 864 & Peixe \\
\hline
\end{tabular}

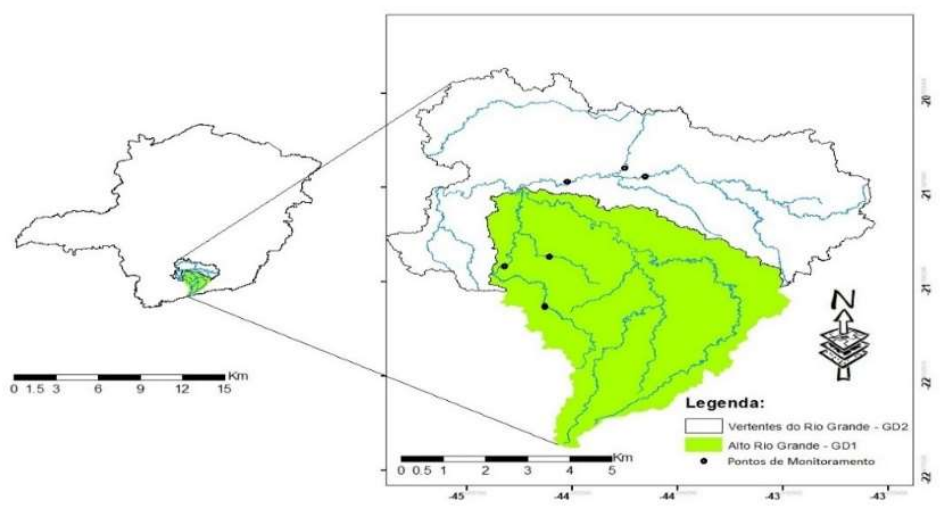

Figure 1: UPGRH (GD1 and GD2) and their respective points.

We collected simple samples (in three widths of the watercourse, being $2 / 3$ from the riverbank to the extremities), using a DH - 49 Suspended Sediment Sampler in vertical movements and the sampling at a depth of about $30 \mathrm{~cm}$. The procedures for sampling and preserving the samples followed the standards established by APHA (2012). The monitoring period took place from April 2015 to February 2016, totaling eight samplings; every two months in the dry season, and monthly in the rainy season.

Analysis of heavy metals were carried out in the Hydrology laboratory at the Water and Soil 
Engineering Center, Engineering Department - DEG/UFLA. The variables evaluated were Aluminum, Bromine, Copper, Hexavalent Chromium, Iron, Manganese, Nickel and Zinc.

The concentrations of heavy metals were compared with the limits established to the supply for human consumption for Class 2 according to the Normative Deliberation (DN) COPAM CERH 01/08. It provides the classification of water bodies and environmental guidelines next to its framework, as well as establishing the conditions and standards for the discharge of effluents and other measures for the final destination of the waters, according to the framework.

The Principal component analysis (PCA) is a method of multivariate statistics that allows interpreting the structure of a set of multivariate data from the respective variance-covariance matrices or correlations between the considered parameters. In this study, we used the correlation matrix, in which the first eigenvalue to be determined corresponds to the highest percentage of the total variability present and so forth. The eigenvectors correspond to the principal components, being the result of the loading of the original variables in each one of them.

The loading matrix for each variable in the principal components when multiplied by the original data matrix will provide the scores matrix for each case in relation to the principal components. These values can be arranged in a dispersion diagram, where the axes are the two most important components and thus show the relationship between the cases conditioned by the measured variables (BERNARDI et al., 2001).

The data were standardized, in general, before the correlation analysis. Thereby, the correlations were generated between the analyzed variables, as they are correlated with each other. We considered PCA as Principal Component Analysis and CP as Principal Component.

\section{RESULTS AND DISCUSSION}

The concentrations of heavy metals for the three points monitored in the Capivari sub-basin are shown in Table 2. The levels of heavy metals in the samples varied for both the dry and rainy seasons.

Aluminum presented concentrations above the maximum allowed value in the eighth sampling campaign at P - I (Ingai - Minduri). It is important to note that this element can be dispersed in the environment due to natural or anthropogenic processes, such as erosion. The high concentrations of Aluminum in contact with humans cause various diseases, especially Alzheimer's (PERL, 1988; FREITAS et al., 2001).

The heavy metal Copper was over the maximum allowed value in the three sampling points during most of the monitoring. According to Moore (1991), Copper may have strong tendencies in fish contamination, with toxicity effects greater than other metals. At the Ingai - Minduri and Capivari sampling points, the concentration of the heavy metal may be associated with the use of fungicides on farms close to the two monitoring points. The influence of seasonality was also observed during the monitored period. According to EPA (1972), concentrations from 0.015 to $3.0 \mathrm{mg}$. $\mathrm{L}^{-1}$ are considered high, hence they are classified as toxic in fresh water, as they compromise many species of fish, crustaceans, mollusks and plankton. The P - III sampling point, on the other hand, had values higher the maximum allowed in five of the 
eight monitored campaigns. Its high concentrations during the rainy season may be associated with pointsource pollution close to the sampling point, such as the inappropriate sewage discharge.

After analyzing Chromium, we found that this heavy metal did not present values higher than the maximum allowed value during the evaluation period in P - I. In P - II, we observed values over the allowed for Chromium in three campaigns. Such results may be associated with the incorrect discharge of industrial effluents (food and poultry industries) close to the monitoring point. Regarding P - III, seasonal influence may have occurred, increasing the concentration in the rainy season. Chromium is released into bodies of water by industries in general, such as tannery, chrome plating, preparation of dyes and minerals (MARTIN et al., 1976; PEREIRA, 2004). There are ore extractions close to the region, a factor that may have resulted in the high levels presented.

Table 2: Concentrations of Heavy Metals, inorganic parameters and comparison with the Class 2 maximum allowed values of COPAM CERH 01/08 - for the Capivari sub-basin (P - I, P - II and P - III). Note: VMP - Maximum Allowed Value for Class 1 of DN COPAM CERH 01/08.

\begin{tabular}{|c|c|c|c|c|c|c|c|c|c|}
\hline \multirow{2}{*}{ Sub - basins } & \multirow{2}{*}{ Date } & \multicolumn{8}{|c|}{ Heavy metals analyzed (mg. $\left.\mathrm{L}^{-1}\right)$} \\
\hline & & Al & $\mathrm{Br}$ & $\mathrm{Cu}$ & $\mathrm{Cr}$ & $\mathrm{Fe}$ & $M n$ & $\mathrm{Ni}$ & $\mathrm{Zn}$ \\
\hline \multirow{8}{*}{$P-1$} & $10 / 04 / 15$ & 0,02 & 0,00 & 0,01 & 0,00 & 1,1 & 0,41 & 0,09 & 0,02 \\
\hline & $29 / 07 / 15$ & 0,07 & 0,05 & 0,01 & 0,00 & 0,6 & 0,30 & 0,03 & 0,09 \\
\hline & $22 / 09 / 15$ & 0,03 & 0,00 & 0,11 & 0,00 & 1,6 & 0,30 & 0,56 & 0,33 \\
\hline & $26 / 10 / 15$ & 0,00 & 0,00 & 0,10 & 0,00 & 1,0 & 0,00 & 0,74 & 0,09 \\
\hline & $23 / 11 / 15$ & 0,01 & 0,35 & 0,58 & 0,01 & 1,9 & 0,40 & 0,49 & 0,06 \\
\hline & $18 / 12 / 15$ & 0,03 & 0,00 & 0,01 & 0,04 & 2,6 & 0,00 & 0,56 & 0,04 \\
\hline & $22 / 01 / 16$ & 0,00 & 0,00 & 0,02 & 0,00 & 3,0 & 0,50 & 0,71 & 0,00 \\
\hline & $19 / 02 / 16$ & 0,12 & 0,00 & 0,17 & 0,00 & 2,1 & 4,40 & 0,70 & 0,00 \\
\hline \multirow{8}{*}{$P-I I$} & $10 / 04 / 15$ & 0,03 & 0,01 & 0,12 & 0,00 & 0,6 & 0,22 & 0,02 & 0,12 \\
\hline & $29 / 07 / 15$ & 0,01 & 0,00 & 0,11 & 0,00 & 0,47 & 0,20 & 0,00 & 0,20 \\
\hline & $22 / 09 / 15$ & 0,06 & 0,0 & 0,06 & 0,03 & 1,10 & 0,50 & 0,00 & 0,19 \\
\hline & $26 / 10 / 15$ & 0,03 & 0,04 & 0,00 & 0,00 & 0,76 & 0,30 & 0,39 & 0,08 \\
\hline & $23 / 11 / 15$ & 0,02 & 0,12 & 0,21 & 0,11 & 0,68 & 0,60 & 0,52 & 0,22 \\
\hline & $18 / 12 / 15$ & 0,00 & 0,88 & 0,21 & 0,05 & 1,48 & 1,40 & 0,34 & 0,36 \\
\hline & $22 / 01 / 16$ & 0,00 & 0,09 & 0,13 & 0,00 & 1,41 & 0,20 & 0,40 & 0,02 \\
\hline & $19 / 02 / 16$ & 0,07 & 0,00 & 0,14 & 0,05 & 1,34 & 1,90 & 0,50 & 0,00 \\
\hline \multirow{8}{*}{$P-I I I$} & $10 / 04 / 15$ & 0,04 & 0,00 & 0,01 & 0,00 & 0,58 & 0,00 & 0,02 & 0,00 \\
\hline & $29 / 07 / 15$ & 0,03 & 0,00 & 0,00 & 0,01 & 1,07 & 2,50 & 0,01 & 0,44 \\
\hline & $22 / 09 / 15$ & 0,02 & 0,02 & 0,11 & 0,00 & 1,25 & 0,00 & 0,02 & 0,02 \\
\hline & $26 / 10 / 15$ & 0,00 & 0,00 & 0,11 & 0,01 & 0,41 & 0,90 & 0,07 & 0,08 \\
\hline & $23 / 11 / 15$ & 0,01 & 0,23 & 0,15 & 0,00 & 1,10 & 0,10 & 0,80 & 0,00 \\
\hline & $18 / 12 / 15$ & 0,02 & 0,01 & 0,34 & 0,00 & 1,45 & 0,00 & 0,01 & 0,00 \\
\hline & $22 / 01 / 16$ & 0,00 & 0,38 & 0,00 & 0,07 & 1,94 & 10,9 & 0,61 & 0,07 \\
\hline & $19 / 02 / 16$ & 0,00 & 0,03 & 0,67 & 0,01 & 1,67 & 0,4 & 0,70 & 0,05 \\
\hline \multicolumn{2}{|l|}{ Mean } & 0,026 & 0,092 & 0,140 & 0,016 & 1,300 & 1,101 & 0,345 & 0,103 \\
\hline \multicolumn{2}{|c|}{ Standard Deviation } & 0,03 & 0,2 & 0,171 & 0,028 & 0,661 & 2,317 & 0,296 & 0,125 \\
\hline \multicolumn{2}{|c|}{ VMP } & 0,1 & - & 0,01 & 0,05 & 0,3 & 0,1 & 0,025 & 0,18 \\
\hline
\end{tabular}

The concentration of iron presented values higher than the allowed during the entire monitoring period, with the highest values observed during the rainy season, which can be associated with the local mineralogy and the rupture and consequent transport of soils upstream.

The heavy metal Manganese presented values higher than the allowed during most of the monitoring in the three sampling points, presenting a behavior similar to iron. Minas Gerais watercourses present high levels of iron and manganese, due to the geochemical characteristics of the basin (BRASIL, 2014). This fact is associated with its own mineralogy and with nonpoint-source pollutions, that is, fertilizer waste and fungicides. 
The heavy metal Nickel presented in all campaigns values over the maximum allowed value for the Ingai - Minduri point and in the other two sampling points throughout the rainy season. According to COPAM (Environmental Policy State Council), an acceptable value is up to $0.025 \mathrm{mg} . \mathrm{L}^{-1}$. In the sections of $\mathrm{P}$ - II and P - III, the values higher than the allowed occurred during the rainy season, due to the influence of the climatic seasonality in the region.

Zinc presented values over the acceptable standard for the monitoring points P - I, P - II and P - III, respectively, which can be associated with the uncontrolled discharge of wastewater, from point-source and nonpoint-source pollutions present in the region.

Figure 2 shows the relationship between the variables of the three Capivari hydrographic sub-basins, through the Biplot of all sampling campaigns at the respective monitoring points. We considered the principal components PC1 and PC2 in the respective campaigns in the monitoring. It is important to note that we obtained the results from the concentration values of heavy metals in the water samples.

Figure 4 shows the Biplot of all sampling campaigns at the respective monitoring points in the Capivari hydrographic sub-basin. In the first sampling campaign, the first principal CP corresponds to $63.5 \%$ of the variability of all data, with the second principal CP corresponding to $36.5 \%$ of the variability of all data. The first $\mathrm{CP}$ represents a general effect of all variables, except $\mathrm{Cr}$, although with a certain predominance of the effects of the variables $\mathrm{Br}, \mathrm{Cu}$ and $\mathrm{Ni}$. In the second $\mathrm{CP}$, it represents a greater effect of Mn. Santos (2008) mentions that in agricultural activity, the presence of the heavy metal $\mathrm{Cu}$ is mainly used in the form of $\mathrm{CuSO}_{4}$, as a fungicide, in the cultivation of grapes and in the control of coffee rust.
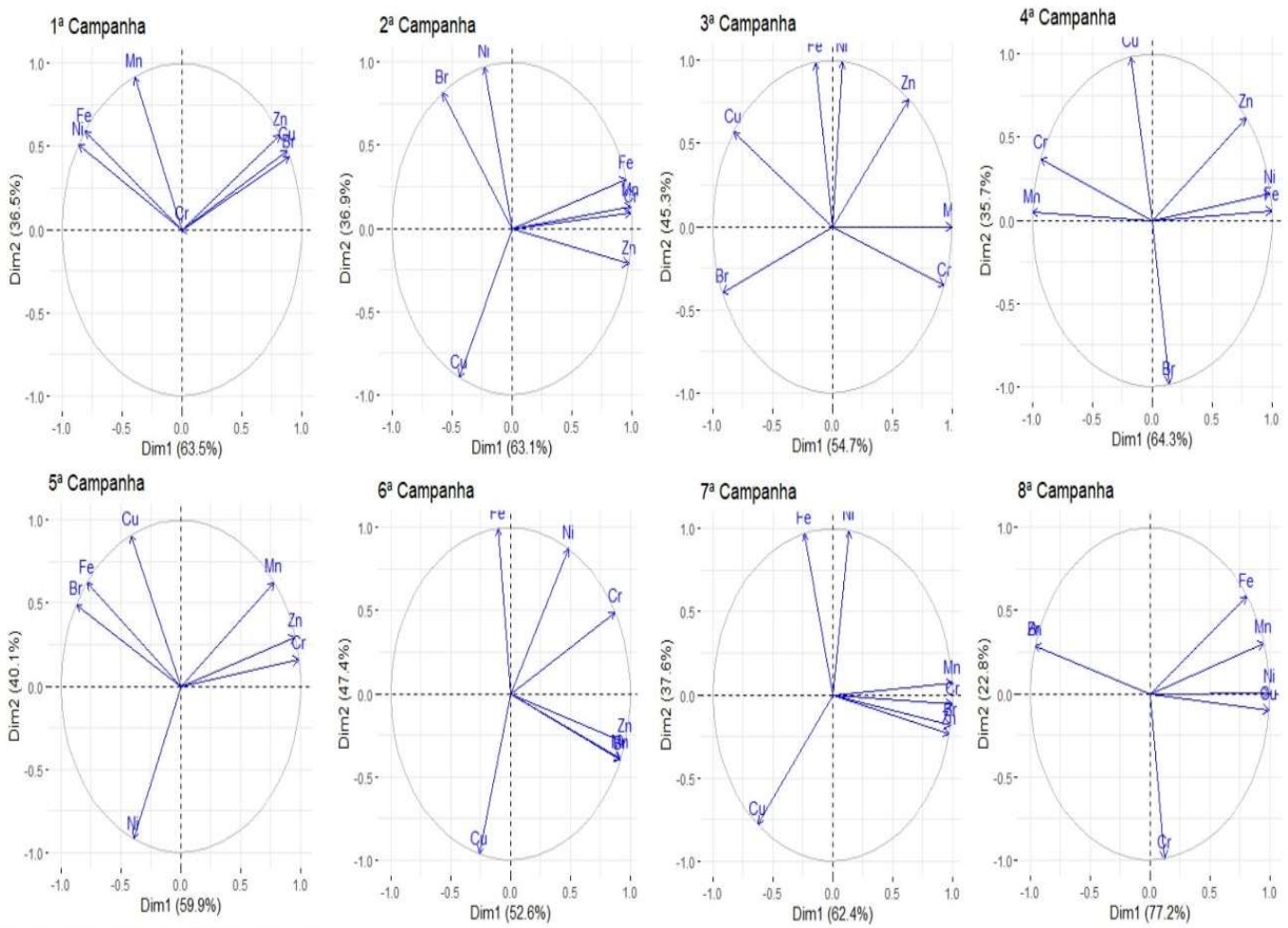

Figure 2: Biplot based on the scores of the campaigns with the UPGRH - GD1.

In the second campaign, the first and second CPs correspond to $63.13 \%$ and $36.9 \%$ of the total data variability, respectively. The first CP represents a general effect of all variables, although with a certain 
predominance of the effects of the variables $\mathrm{Cr}, \mathrm{Mn}, \mathrm{Zn}$ and Fe and the second $\mathrm{CP}$ represents a greater effect of $\mathrm{Ni}, \mathrm{Cu}$ and $\mathrm{Br}$. An example is Manganese, which is an essential trace element in the physiological processes of plants and animals. However, in high concentrations it can become toxic. Its contamination has attracted the attention of researchers mainly due to the intensification of the discharging of this element in the water. In addition to occurring naturally in the environment, this metal can also come from anthropogenic activities, through discharges from manufacturing industries such as paper, metal and chemicals, and domestic waste (BANKS et al., 1997; JESUS et al., 2015).

In the third campaign, the first CP corresponds to $54.7 \%$ of the total variation of the data and the second, to $45.3 \%$. The first CP represents a general effect of all variables, although with a prevalence of the effects of the variables $\mathrm{Mn}, \mathrm{Cr}, \mathrm{Br}$ and $\mathrm{Cu}$, whilst the second $\mathrm{CP}$ represents a greater effect of $\mathrm{Ni}$ and $\mathrm{Fe}$, due to the presence of point-source pollutions, mainly associated with the discharge of untreated industrial effluents.

In the fourth campaign, the first CP corresponds to $64.27 \%$ of the total variability of the data, representing a certain prevalence of the effects of the variables $\mathrm{Mn}, \mathrm{Fe}, \mathrm{Ni}$ and $\mathrm{Cr}$, which is mainly associated with the point-source and nonpoint-source pollutions and with the increase of rainfall, which carried several trace elements to the sampling points (AMANCIO et al., 2020). The second principal CP corresponds to $35.7 \%$ of the variability of all data, being represented by the effects of the variables $\mathrm{Br}, \mathrm{Cu}$ and $\mathrm{Zn}$ with a certain predominance.

The fifth campaign showed that the first $\mathrm{CP}$ represents a predominance of the effects of the variables $\mathrm{Cr}$ and $\mathrm{Zn}$ and is responsible for $59.9 \%$ of the total variation of the data. The second $\mathrm{CP}$, on the other hand, represents a predominance of the effects of the variables $\mathrm{Ni}$ and $\mathrm{Cu}$, with a value of $40.1 \%$ of the total data variability. In Populina, Sao Paulo, Paganini et al. (2004) presented high values of mercury, nickel, lead and aluminum at all depths in the work carried out in the described location. The results found were close to the sewage treatment station, as it gradually affects the region's surroundings, mainly due to the contamination of groundwater.

In the sixth campaign, the first principal component is responsible for $52.6 \%$ of the total variability of the data, with a greater effect of $\mathrm{Zn}, \mathrm{Mn}, \mathrm{Br}$ and $\mathrm{Cr}$. The second principal $\mathrm{CP}$ corresponds to $47.4 \%$ of the variability of all data, corresponding to a predominance of the effect of $\mathrm{Fe}, \mathrm{Cu}$ and $\mathrm{Ni}$. The responses in the two principal components were associated with high precipitation carrying different amounts of pollutants from point-source and nonpoint-source pollutions in the region (AMANCIO et al., 2018).

The first and second $\mathrm{CP}$, for the seventh campaign, correspond to the total variability of the data with $62.4 \%$ and $37.6 \%$, respectively. The first CP represents a predominance of the effects of the variables $\mathrm{Cr}, \mathrm{Mn}$, $\mathrm{Br}$ and $\mathrm{Zn}$, and the second presents a predominance of heavy metals $\mathrm{Ni}$ and $\mathrm{Fe}$, a similar situation to the sixth campaign.

In the last sampling campaign related to UPGRH GD1, the first CP corresponds to $77.2 \%$ of the total data variability and the second, to $22.8 \%$. Their values are associated, respectively, with a certain predominance of $\mathrm{Ni}, \mathrm{Cu}, \mathrm{Zn}, \mathrm{Br}$ and $\mathrm{Mn}$ for the first $\mathrm{CP}$, and in the second, for $\mathrm{Cr}$ and Fe. Near the monitoring 
points, the incorrect use of pesticides may have led large amounts of pollutants into the watercourse. Pointsource pollution can be associated, since we can clearly see the incorrect discharge of untreated domestic effluents.

Table 3 below shows concentrations for heavy metals during the monitoring at Vertentes do Rio Grande (GD2) at three monitoring points, together with the maximum allowed values for Class 2 according to DN COPAM CERH 01/08.

Table 3: Values of the Heavy Metals samples, inorganic parameters and comparison with the Class 1 maximum allowed values of COPAM CERH 01/08 - for the Mortes sub-basin (P - IV, P - V and P - VI). Note: VMP - Maximum Allowed Value for Class 1 of DN COPAM CERH 01/08.

\begin{tabular}{|c|c|c|c|c|c|c|c|c|c|}
\hline \multirow{2}{*}{ Sub - Basins } & \multirow{2}{*}{ Date } & \multicolumn{8}{|c|}{ Analyzed heavy metals (mg. $\mathrm{L}^{-1}$ ) } \\
\hline & & Al & $\mathrm{Br}$ & $\mathrm{Cu}$ & $\mathrm{Cr}$ & $\mathrm{Fe}$ & Mn & $\mathrm{Ni}$ & $\mathrm{Zn}$ \\
\hline \multirow{8}{*}{$P-I V$} & 28/04/15 & 0,02 & 0,00 & 0,10 & 0,02 & 1,17 & 0,00 & 0,06 & 0,09 \\
\hline & 22/07/15 & 0,04 & 0,06 & 0,07 & 0,02 & 0,75 & 0,30 & 0,02 & 0,53 \\
\hline & $15 / 09 / 15$ & 0,02 & 0,00 & 0,03 & 0,00 & 1,46 & 0,20 & 0,04 & 0,00 \\
\hline & 19/10/15 & 0,01 & 0,11 & 0,06 & 0,00 & 0,55 & 0,10 & 0,02 & 0,52 \\
\hline & $16 / 11 / 15$ & 0,29 & 3,90 & 0,84 & 0,07 & 3,87 & 15,2 & 0,92 & 0,29 \\
\hline & $14 / 12 / 15$ & 0,50 & 2,96 & 0,67 & 0,30 & 3,22 & 13,0 & 0,66 & 0,00 \\
\hline & $19 / 01 / 16$ & 0,07 & 0,13 & 0,17 & 0,03 & 2,68 & 0,50 & 0,43 & 0,13 \\
\hline & $17 / 02 / 16$ & 0,05 & 0,30 & 0,02 & 0,01 & 1,21 & 0,00 & 0,02 & 0,14 \\
\hline \multirow{7}{*}{$P-V$} & $22 / 07 / 15$ & 0,01 & 0,12 & 0,00 & 0,02 & 0,54 & 0,10 & 0,02 & 0,38 \\
\hline & $15 / 09 / 15$ & 0,03 & 0,00 & 0,00 & 0,00 & 1,10 & 0,10 & 0,02 & 0,03 \\
\hline & $19 / 10 / 15$ & 0,03 & 0,00 & 0,04 & 0,02 & 0,66 & 0,20 & 0,00 & 0,04 \\
\hline & $16 / 11 / 15$ & 1,00 & 7,91 & 1,0 & 0,30 & 4,32 & 19,6 & 0,94 & 0,05 \\
\hline & $14 / 12 / 15$ & 0,35 & 3,33 & 0,78 & 0,30 & 2,67 & 16,4 & 0,83 & 0,03 \\
\hline & $19 / 01 / 16$ & 0,02 & 0,00 & 0,03 & 0,02 & 2,25 & 4,4 & 0,55 & 0,14 \\
\hline & $17 / 02 / 16$ & 0,02 & 0,00 & 0,12 & 0,03 & 2,66 & 0,2 & 0,08 & 0,07 \\
\hline \multirow{8}{*}{$P-I V$} & $14 / 05 / 15$ & 0,01 & 0,10 & 0,00 & 0,00 & 0,59 & 0,20 & 0,01 & 0,00 \\
\hline & $22 / 07 / 15$ & 0,01 & 0,02 & 0,04 & 0,00 & 0,55 & 0,00 & 0,01 & 0,20 \\
\hline & $15 / 09 / 15$ & 0,06 & 0,01 & 0,04 & 0,03 & 1,20 & 0,20 & 0,00 & 0,00 \\
\hline & $19 / 10 / 15$ & 0,00 & 0,00 & 0,05 & 0,00 & 0,51 & 0,00 & 0,42 & 0,14 \\
\hline & $16 / 11 / 15$ & 0,00 & 0,11 & 0,00 & 0,00 & 1,02 & 0,00 & 0,66 & 0,10 \\
\hline & $14 / 12 / 15$ & 0,01 & 0,21 & 0,10 & 0,02 & 1,25 & 0,00 & 0,05 & 0,15 \\
\hline & $19 / 01 / 16$ & 0,00 & 0,00 & 0,00 & 0,02 & 3,73 & 0,30 & 0,02 & 0,09 \\
\hline & $17 / 02 / 16$ & 0,04 & 0,03 & 0,08 & 0,01 & 1,79 & 0,30 & 0,77 & 0,01 \\
\hline \multicolumn{2}{|c|}{ Mean } & 0,113 & 0,839 & 0,184 & 0,053 & 1,728 & 3,100 & 0,285 & 0,136 \\
\hline \multicolumn{2}{|c|}{ Standard Deviation } & 0,232 & 1,926 & 0,307 & 0,099 & 1,198 & 6,224 & 0,350 & 0,155 \\
\hline \multicolumn{2}{|c|}{ VMP } & 0,1 & - & 0,01 & 0,05 & 0,3 & 0,1 & 0,025 & 0,18 \\
\hline
\end{tabular}

The heavy metal Aluminum showed concentrations higher than the maximum allowed value in two campaigns, both for the sampling point $\mathrm{P}$ - IV and $\mathrm{P}$ - V.Its values may be associated with the sources of pollution upstream of the Mortes sampling point, such as the incorrect discharge of packages and residues of food.

Copper had values higher than what was allowed in all campaigns monitored in P - IV.Its high values may be associated with contamination around the basin. In the past, the region has been the target of gold mining and, currently, mines are found upstream from where the sampling took place. The results higher than the maximum allowed values during the rainy season in the $\mathrm{P}-\mathrm{V}$ (Peixe River) had a critical influence of seasonality. The agricultural use of fungicides can be correlated with the results found.

The heavy metal Chromium presented values higher than the allowed only in the sampling points Mortes $(P-I V)$ and Peixe $(P-V)$, with one and two sampling campaigns, respectively. According to Magro et al. (2013), large concentrations of Chromium can compromise aquatic life due to changes in the immune 
system, causing infections.

The high concentrations of iron showed that the high precipitations were essential in the results. The soils of the state of Minas Gerais have high levels of iron.

Manganese showed variations in behavior between the three sampling points of GD2. It is important to highlight the high concentrations found in campaigns $16 / 11 / 2015$ and $14 / 12 / 2015$, both for $P$ - IV and for $\mathrm{P}-\mathrm{V}$, with concentrations of 15.2 and $13 \mathrm{mg} . \mathrm{L}^{-1}(\mathrm{P}-\mathrm{IV})$ and 19.6 and $16.4 \mathrm{mg}^{-1}(\mathrm{P}-\mathrm{V})$, respectively. We believe that high rainfall in the days prior to the sampling and the discharge of pollutants upstream of the Mortes sampling point influenced this behavior, associated with mining (AMANCIO et al., 2018). In the same campaigns, higher concentrations were found in Peixe River, which may be correlated with nonpoint-source pollutions, such as the decomposition of organic matter that releases organic compounds, which is generally compromised by the use and occupation of soil in the basin.

The heavy metal Nickel presented concentrations higher than the maximum allowed values in the three sampling points. Whilst in P - IV they were found in the dry and rainy seasons, in the others, they occurred only in the rainy season. The high values can be associated with nonpoint-source pollutions from galvanic industries.

Zinc presented values over the allowed in three sampling points of the Mortes sub-basin. At (P - IV), in the dry and rainy seasons. Its behavior may be associated with the accumulation of materials from metallurgical industries.

Figure 3 shows the relationship between the UPGRH GD2 variables. The principal components PC1 and PC2 are considered in the respective campaigns within the monitoring. It is important to emphasize that the results were obtained from the concentration values of heavy metals in the water samples.

According to the data found, the first sampling campaign registered values of $87.6 \%$ and $12.4 \%$ for the first and second CPs, respectively. The first principal component has a general effect of all variables, although with a certain predominance of the effects of Fe in larger numbers, followed by $\mathrm{Ni}, \mathrm{Mn}$ and $\mathrm{Br}$. The second CP has a greater effect for $\mathrm{Zn}$. Sabino (2008) mentions that the loading components and the maximums location suggest that this component is related to the impact of urban and industrial effluents on the water quality of the Paraopeba River sub-basin. This finding can be explained by the dilution of pollutants in the rainy season. The discharge of wastewater is practically constant, but the increase in flow due to rain causes dilution. The water quality variables that affected were chloride, sulfate, nitrate, nitrite, barium, boron, copper, chromium, iron and zinc.

In the second campaign, the first CP corresponds to $68.2 \%$ of the variability of the data with a general effect of all variables, although with a certain predominance of the effects of the variables $\mathrm{Zn}, \mathrm{Mn}, \mathrm{Ni}$ and $\mathrm{Cr}$. The second principal CP corresponds to $31.8 \%$ of the variability of all data, which represents a greater effect of $\mathrm{Br}$ and $\mathrm{Cu}$. Locations close to the sampling point can be related to the variables with greater predominance, since they come from the discharge of industrial effluents. 

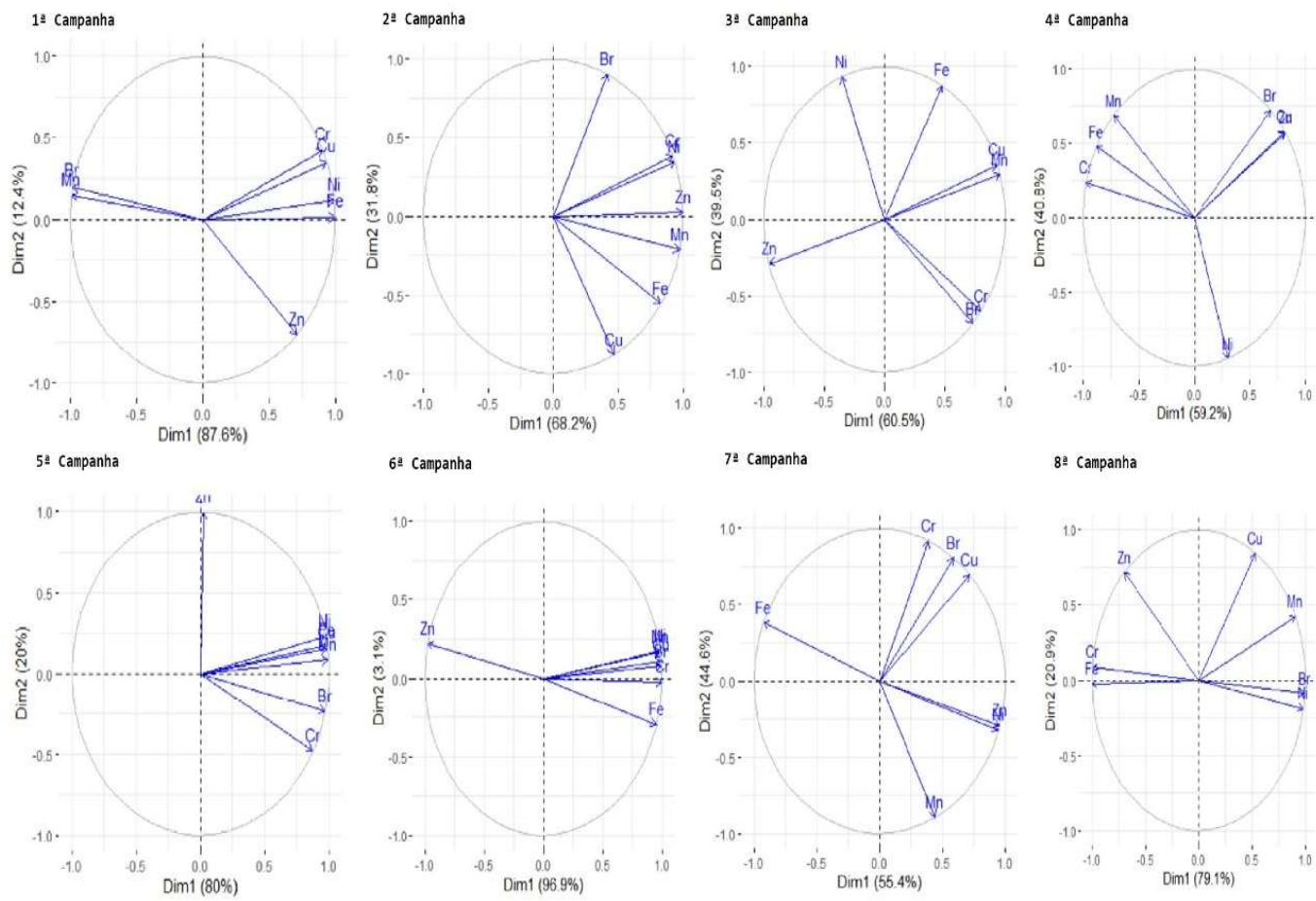

Figure 3: Biplot based on the scores of the campaigns along with UPGRH - GD2.

For the third campaign, the total data variability registered $60.5 \%$ and $39.5 \%$ for the first and second $\mathrm{CP}$, respectively. Values associated with the first $\mathrm{CP}$ registered a predominance for the heavy metals $\mathrm{Zn}, \mathrm{Mn}$ and $\mathrm{Cu}$. In the second $\mathrm{CP}$, for $\mathrm{Ni}$ and $\mathrm{Fe}$. The seasonality might have influenced the values with a predominance of $\mathrm{Zn}, \mathrm{Mn}$ and $\mathrm{Cu}$ in larger amounts and in those of smaller amounts such as $\mathrm{Ni}$ and $\mathrm{Fe}$, hence increasing the concentration in the rainy season.

In the fourth sampling campaign, the total data variability for the first CP corresponded to $9.22 \%$, and for the second $\mathrm{CP}$, to $40.8 \%$. Results found for the first $\mathrm{CP}$ are associated with the predominance of the effects of heavy metals $\mathrm{Cr}, \mathrm{Fe}, \mathrm{Zn}$ and $\mathrm{Cu}$. In the second $\mathrm{CP}$, the predominant effect was $\mathrm{Ni}$.

In the fifth and sixth campaigns, the values recorded during the monitoring were much higher in comparison to the other campaigns, due to the large amount of sediments and rainfall, which are responsible for the high values we found. In the fifth campaign, the first CP corresponds to $80.02 \%$ of the total variation of the data, and the second, to $19.98 \%$. For the first CP, the effect of the most prominent variables were $\mathrm{Cu}$, $\mathrm{Fe}$, Ni and $\mathrm{Br}$, whilst in the second $\mathrm{CP}$, the predominant variable was the heavy metal $\mathrm{Zn}$. Singh et al. (2004) mentions in his work in India that the loading components with greater predominance are related to mining activities, a similar factor around the monitoring points.

In the sixth campaign, the values found for the first and second CP were respectively $96.9 \%$ and $3.1 \%$ of the total data variability. In the first $\mathrm{CP}$, the predominance of heavy metals, in general, represents the effect of all variables. In the second, on the other hand, there is a smaller predominance of Fe. Due to the high rainfall in the region, the transport of particles from soil release, organic matter, untreated domestic and industrial effluents and pesticides can be correlated to the values with greater predominance in the first CP.

In the seventh campaign, the first CP corresponds to $55.4 \%$ of the total variability of the data and the 
second to $44.6 \%$. In the first $\mathrm{CP}$, there is a certain predominance of the heavy metals $\mathrm{Zn}, \mathrm{Ni}$, $\mathrm{Fe}$ and $\mathrm{Cu}$, and these are associated with mining activities coming upstream from the sampling point and with the use of pesticides. Hence, such factors may have been crucial for the high predominance in the first PC. In the second PC, there is a predominance of $\mathrm{Cr}$ and $\mathrm{Mn}$. According to Fostier et al. (2000), the release of heavy metals to the water in a mineral extraction area are up to $9.3 \mu \mathrm{g} \mathrm{m}^{2}$ per year for $\mathrm{Hg}$ and $2.1 \mu \mathrm{g} \mathrm{m} \mathrm{m}^{2}$ per year for $\mathrm{Mg}$, Fe, Mn and Zn (FOSTIER et al., 2000; LIMA et al., 2015). In addition, during the mining and processing of gold in mining areas, elements such as $\mathrm{Cu}, \mathrm{Pb}$ and $\mathrm{Zn}$ are concentrated and released directly into watercourses, as seen in areas with a history of contamination (RODRIGUES FILHO et al., 1997; CESAR et al., 2009).

In the last GD2 sampling campaign, the first and second CPs correspond to $79.14 \%$ and $20.86 \%$ of the total data variability. In the first $\mathrm{CP}$, there is a predominance of the heavy metals $\mathrm{Fe}, \mathrm{Br}$ and $\mathrm{Ni}$, whilst in the second $\mathrm{CP}$ there is a predominance of $\mathrm{Cu}$ and $\mathrm{Zn}$. Such values are associated with high rainfall levels and nonpoint-source pollutions from galvanic industries.

On average, CP 1 corresponds to $62.2 \%$ of the total variability of the data considering the data from the three sub-basins monitored in GD 1. In the three sub-basins in GD 2, CP 1 is responsible for a higher average percentage of the total variability of the data, of $73.4 \%$. Therefore, CP 1 represents better the variability present in GD 2. Corroborating what was found in the analysis, it is known that in rivers, the concentrations of metals in suspended sediments are generally higher than the concentration dissolved in the water column, although the transfer of metals between such compartments are related to the characteristics of the metal ion, the size of the particles, the organic content and their concentration in the sediment. However, in highly contaminated environments by heavy metals, the prominent levels in the dissolved form can be relatively high (ALVES et al., 2010).

\section{CONCLUSIONS}

The high amounts of heavy metals present in the Capivari River hydrographic sub-basin, at the three evaluated points, may be associated with mineral exploration, point and nonpoint-source pollutions;

In the Mortes River hydrographic sub-basin, results over the allowed values for heavy metals can be correlated to the large amount of suspended sediments that was found and these can be mainly associated with the discharge of untreated effluents from industries and mining;

According to the results, the CP 1 relative to GD1 was more representative than in GD2, showing a correlation between the main heavy metals and anthropic activities, such as $\mathrm{Zn}, \mathrm{Fe}, \mathrm{Cu}$ and $\mathrm{Ni}$ and the pointsource and nonpoint-source pollutions close to the monitoring points, the main ones from agricultural and mining activities and the incorrect discharging of untreated effluents.

\section{REFERENCES}

ALVES, R. I. S.; TONANI, K. A. A.; NIKAIDO, M.; CARDOSO, O. O.; TREVILATO, T. M. B.; SEGURAMUÑOZ, S. I.. Avaliação das concentrações de metais pesados em águas superficiais e sedimentos do Córrego Monte Alegre e afluentes, Ribeirão Preto, SP, Brasil. Ambi-Agua, Taubaté, v.5, n.3, p.122-132,
2010.

AMANCIO, D. V.; COELHO, G.; MARQUES, R. F. P. V.; VIOLA, M. R.; MELLO, C. R.. Qualidade da água nas sub-bacias hidrográficas dos rios Capivari e Mortes, Minas Gerais. 
Scientia Agraria, Curitiba, v.18, n.4, 2018.

AMANCIO, D. V.; COELHO, G.; MARQUES, R. F. P. V.; SILVA, R. A.. Avaliação da Descarga Sólida em suspensão nas subbacias hidrográficas dos Rios Capivari e Mortes. Revista Sustentare, v.4, n.1, 2020.

APHA. American Public Health Association. Standard Methods For The Examination of Water and Wastewater. 22 ed. Washington: APHA, 2012.

BANKS, D.; YOUNGER, P. L.; ARNESEN, R. T.; IVERSEN, E. R.; BANKS, S. B.. Minewater chemistry: the good, the bad and the ugly. Environmental Geology, v.32, n.157, 1997.

BRASIL. Ministério da Saúde. Fundação Nacional de Saúde. Manual de controle da qualidade da água para técnicos que trabalham em ETAS. Ministério da Saúde, Fundação Nacional de Saúde. Brasília: Funasa, 2014.

CESAR, R. G.; EGLER, S. G.; POLIVANOV, H.; RODRIGUES, A. P. C.; FERNANDES, V. A.; SILVA, M. B.; CASTILHOS, Z. C.; ARAUJO, P. C.. Metais pesados em solos e sedimentos fluviais em antiga área de garimpo de ouro em Descoberto, Minas Gerais. Rio de Janeiro: CETEM, 2009.

FOSTIER, A. H.; FORTI, M. C.; GUIMARAES, J. R. D.; MELFI, A. J.; BOULET, R.; SANTO, C. M.; KRUG, F. J.. Mercury fluxes in a natural forested Amazonian catchment, Serra do Navio, Amapá State, Brazil. The Science of the Total Environment, v.260, p.201-211, 2000.

JESUS, T. B.; SOUZA, S. S.; SANTOS, L. T. S. O.; AGUIAR, W. M.. Avaliação da potencialidade de utilização de espécies de macrófitas como acumuladoras de metais pesados. Revista Virtual de Química, v.7, n.4, p.1102-1118, 2015.

LIMA, D. P.; SANTOS, C.; SILVA, R. S.; YOSHIOKA, E. T. O.; BEZERRA, R. M.. Contaminação por metais pesados em peixes e água da bacia do rio Cassiporé, Estado do Amapá, Brasil. Acta Amazonica, v.45, n.4, p.405-414, 2015.

MAGRO, C. D.; DEON, M. C.; THOMÉ, A.; PICCIN, J. S.; COLLA, L. M.. Biossorção passiva de Cromo (IV) através da microalga Spirulina platensis. Química Nova, São Paulo v.36, n.8, p.1-7,
2013.

MARTIN, J. M.; MEYBECK, M.; SALVADOR, F.; THOMAS, A. Pollution chimique des estuaries: état des connaissances. Centre national pour i'exxplotation des oceans. Série report scientifiques et techbiques. 1976.

MINAS GERAIS. Deliberação normativa conjunta COPAM/CERH-MG, no. 01, de 05 de maio de 2008. Belo Horizonte, 2008.

MINAS GERAIS. Secretaria de Estado de Meio Ambiente e Desenvolvimento Sustentável. Zoneamento ecoloógico: econômico do Estado de Minas Gerais - ZEE-MG. Belo Horizonte, 2008.

PAGANINI, W. S.; SOUZA, A.; BOCCHIGLIERI, M. M.. Avaliação do comportamento de metais pesados no tratamento de esgotos por disposição no solo. Eng. sanit. Ambient., v.9, n.3, p.225-239, 2004.

PEREIRA, R. S.. Identificação e caracterização das fontes de poluição em sistemas hídricos. Revista Eletrônica de Recursos Hídricos, v.1, n.1, p.20-36, 2004.

RODRIGUES FILHO, S.; MADDOCK, J. E. L.. Assessment of the heavy metal pollution in a gold "garimpo". Tecnologia Ambiental, v.7, p.1-32, 1997.

SABINO, C. V. S.; ABREU, J. F.; LOBATO, W.; SABINO, G. S.; KNUP, E. A. N.. Análise de alguns aspectos da qualidade da água da Bacia do Rio Paraopeba utilizando estatística multivariada. Revista de Biologia e Ciências da Terra, v.8, n.2, 2008.

SANTOS, M. L.; LENZI, E.; COELHO, A. R.. Ocorrência de metais pesados no curso inferior do rio Ivaí, em decorrência do uso do solo em sua bacia hidrográfica. Acta Sci. Technol., Maringá, v.30, n.1, p.99-107, 2008

SINGH, K. P.; MALIK, A.; MOHAN, D.; SINHA, S.. Multivariate statistical techniques for the evaluation of spatial and temporal variations in water quality of Gomti River (India)--a case study. Water Research., v.38, n.18, p.3980-92, 2004. DOI: https://doi.org/10.1016/j.watres.2004.06.011

A CBPC - Companhia Brasileira de Produção Científica (CNPJ: 11.221.422/0001-03) detém os direitos materiais desta publicação. Os direitos referem-se à publicação do trabalho em qualquer parte do mundo, incluindo os direitos às renovações, expansões e disseminações da contribuição, bem como outros direitos subsidiários. Todos os trabalhos publicados eletronicamente poderão posteriormente ser publicados em coletâneas impressas sob coordenação da Sustenere Publishing, da Companhia Brasileira de Produção Científica e seus parceiros autorizados. Os (as) autores (as) preservam os direitos autorais, mas não têm permissão para a publicação da contribuição em outro meio, impresso ou digital, em português ou em tradução. 